\title{
Evaluate Tectonic Activity of Tehran City (Iran) Based on Geomorphic Indices, Field Investigation and Remote Sensing Study
}

\author{
Z. Mohammadi Asl ${ }^{1 *}$, M. R. Abbassi ${ }^{2}$ \\ ${ }^{1}$ Department of Geophysics, Graduate School of Science, Kyoto University, Kyoto, Japan \\ ${ }^{2}$ International Institute of Earthquake Engineering and Seismology, Tehran, Iran \\ Email: ${ }^{\star}$ z_mohammadiasl@yahoo.com, ${ }^{*}$ Mohammadi.zara.37c@kugi.kyoto-u.ac.jp
}

How to cite this paper: Mohammadi Asl, Z. and Abbassi, M.R. (2019) Evaluate Tectonic Activity of Tehran City (Iran) Based on Geomorphic Indices, Field Investigation and Remote Sensing Study. Open Journal of Earthquake Research, 8, 19-36. https://doi.org/10.4236/ojer.2019.81002

Received: October 22, 2018

Accepted: January 8, 2019

Published: January 11, 2019

Copyright $\odot 2019$ by author(s) and Scientific Research Publishing Inc. This work is licensed under the Creative Commons Attribution International License (CC BY 4.0).

http://creativecommons.org/licenses/by/4.0/

\begin{abstract}
Active tectonics in the south part of Alborz Mountain (Iran) has greatly influenced the drainage system and geomorphic expressions. The metropolis of Tehran is located at the southern foothills of the Alborz Mountains at the abrupt topographic boundary between the mountain range and the northern border of the central Kavir Desert. The presence of active faults and tectonic activity, threatens the area and shows the vulnerability of this Tehran city. So the evaluation of active tectonics of Tehran City is necessary because of vast human activity, which has hidden geomorphic feature. Active tectonics of Tehran City was evaluated by using Digital elevation model (DEM) derived drainage network and three geomorphic indices basin (asymmetry factor (AF), basin shape index (Bs) and mountain front sinuosity (Smf)). The average of the three measured geomorphic indices was used to evaluate the distribution of relative tectonic activity in the study area. Furthermore to overcome some inevitable error in this method, field investigation was carried out also remote sense was studied, and finally the obtained results were compared with existing seismic data. The result confirms that the East South, East North and West North Tehran have high rate of relative tectonic activity (RTA) respectively.
\end{abstract}

\section{Keywords}

Alborz Mountain, Geomorphic Indices, Asymmetry Factor, Basin Shape Index, Mountain Front Sinuosity

\section{Introduction}

Landscapes in tectonically active Alborz Mountains are the result of complex in- 
tegration of the effects of the Arabian-Eurasian convergence and clockwise rotation of the south Caspian basin with respect to Eurasia. In the active area, the rate of activity and rock uplift could be considered as the main factor with contribution of erosional processes that could control present-days topography of area [1] [2]. The active processes have an important role for making the shape of the drainage pattern in tectonically active regions and control drainage geometry and river deflections; basin asymmetries also are responsible for accelerated river incision [3]. The high populated Tehran in the southern domain of the Alborz Mountains is the eastern branch of the Alpine-Himalayan orogeny in Iran. This megacity is located near seismically active faults in the north, [4] [5]. The presence of diverse fault orientations showing evidence of internal post-Pleistocene deformation in this zone and the existence of historical and instrumental data confirm the seismic hazard treating the city, showing the vulnerability of this city. Considering the fact that, the Tehran city has not experienced any major destructive earthquakes for around 200 years, it is necessary to study the evaluation of tectonic activity of Tehran City. The study area has been developed on recent alluvial deposits originating from the rising of Alborz Range, accumulated on hard rock through complex geological formations [6].

In this study tectonic activity of Tehran City was evaluated and they were tried to classify and specify the high tectonic activity areas. Three significant morphometric indices were used for this evaluation: drainage basin asymmetry (Af), drainage basin shape (Bs) and mountain front sinuosity (Smf). It is necessary to express that some error would be inevitable in this method's results, due to the impact of various factors such as various deposits of sediments, different weather conditions and different levels of erosion. So to overcome this problem, field investigation was carried out and remote sensing was studied based on satellite image, aria photos and Google Earth. Finally their obtained results have been compared with existing historical earthquake and micro-seismic records during past 11 years (2006 till 2017). The aim of this study is to characterize the activity of faults in zones (faults) of Tehran City for better understanding of the tectonics which could provide a better planning of future studies in this area.

\section{Geological Setting}

The tectonic activity in the Alborz mountain range, northern Iran, is results of both to the northward convergence of central Iran toward Eurasia, and to the northwestward motion of the South Caspian Basin with respect to Eurasia inducing a left-lateral wrenching along this range. These two mechanisms give rise to a NNE-SSW transpressional regime. The GPS measurements shown NNE-directed shortening with a rate of $5 \pm 2 \mathrm{~mm} \mathrm{yr}^{-1}$; In addition, a range-wide shearing is observed at a rate of $4 \pm 2 \mathrm{~mm} \mathrm{yr}^{-1}$, which is related with left-lateral motion on E-W striking structures [7] [8] (Figure 1).

\section{Methodology}

In recent decades various researchers along morpho-tectonic quality indices, 


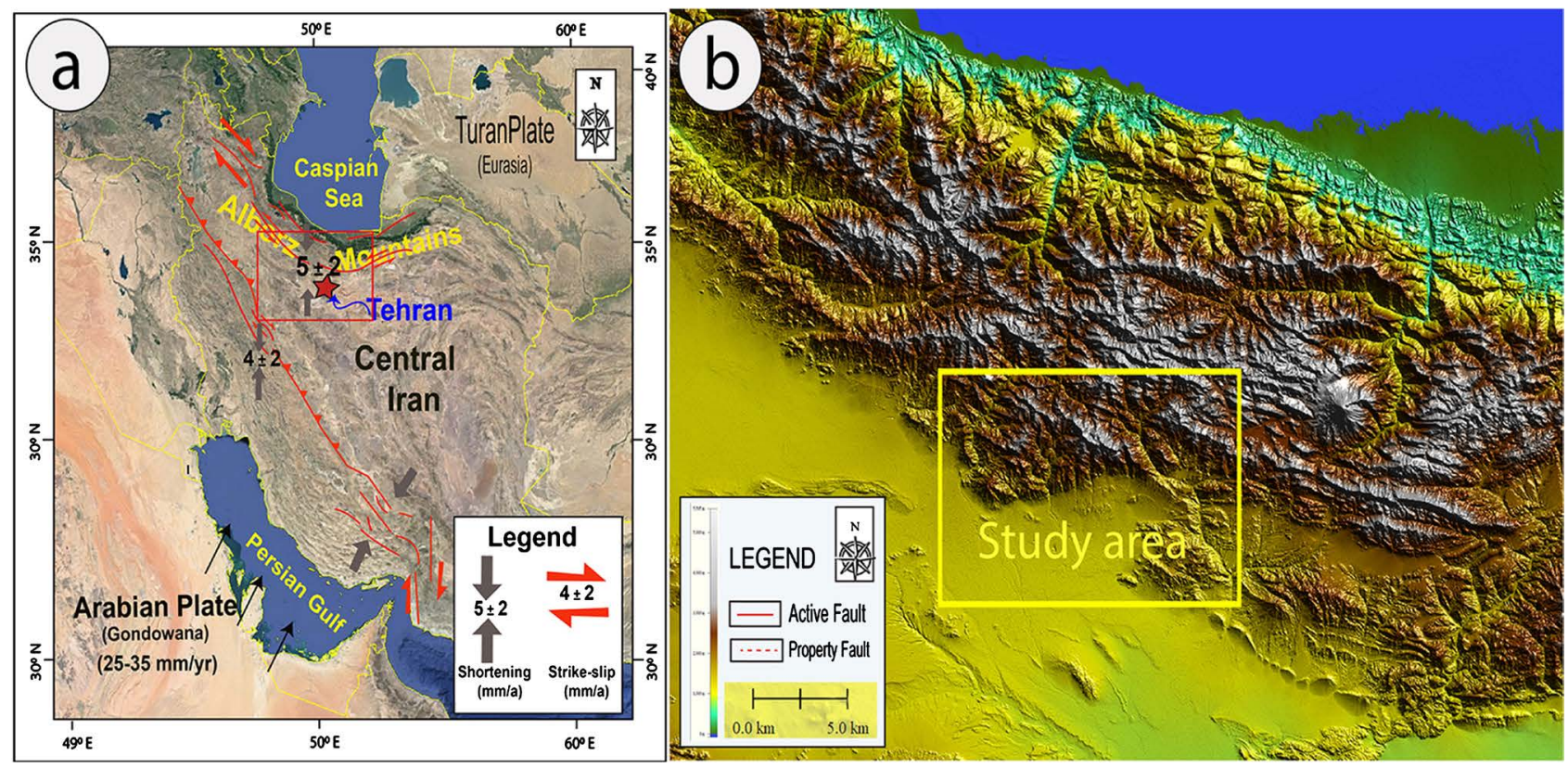

Figure 1. (a) Simplified tectonic map of the Middle East with arrows showing sense of relative motion. Relative displacement in the central Alborz Mountains (modified after [8]; (b) Location of study area (Tehran city) on the color-shaded relief maps generated by 1:30,000 digital elevation model.

have tried to quantify the behavior of tectonic movements. Quantitative measurements and numerical geomorphologists give the opportunity to evaluate different landform real and tangible. Neo-tectonic of tectonic activity is defined as the consequences of this movement can be observed in the faults, alluvial fans, alluvial plains and morphometric watershed system on the active foothills. In this research, three morphometric indices were assessed. Morphometric indices are known to be useful for categorizing of activity level in active tectonic subjects. These studies are also important in evaluating earthquake hazards, in particular those areas with relatively high activity such as in the Holocene and late Pleistocene [9] [10] [11] [12]. In the present studies with focus onmountain fronts, tectonic activities was analyzed based on drainage basin asymmetry (Af), drainage basin shape (Bs) and mountain front sinuosity (Smf) indices [13] [14]. A combination of these indices of geomorphological features results, with geographic information systems (GIS), remote sensing study, field investigation and Micro-seismic records provides us a valuable quantitative method. This procedure presents relative rates of tectonic activity [15] and this procedure previously has been used by researchers in tectonically active areas such as SW USA [13], In Hindu Kush [16] and in different part of Iran [17].

\subsection{Morphometric Analysis and Results}

GiRockwellen [13] selected morphologic attributes of tectonic landforms, one can determine the corresponding tectonic history; or similarly, given information about the tectonic history, can one determine how landforms will evolve in high elevation ranges, the recent tectonics activity tectonics could observed as 
the main reason for uplifting and competition of erosional process and tectonic control the topographical feature of mountains [1] [2]. Tectonic geomorphology is the study of landforms that result from tectonism and the interaction between tectonic and geomorphic processes and can distinguish the timing and distribution of events have occurred over thousands of years in the mountain fronts. The geomorphic indices are based on analysis of the drainage network in mountain fronts. These indices may detect anomalies in the drainage system or along mountain fronts [15], also the drainage system is very sensitive to active processes such as folding and faulting which are responsible for accelerated river incision, basin asymmetries, drainage geometry and complexity and river deflections [3]. Drainage pattern and morphometric indices could be efficient way when there are limitation in field investigation such as Military Areas (some part of eat Tehran) or high mountain range to climb (Some part of north Tehran). It is necessary to express that some error would be inevitable in this method results, Due to the impact of various factors such as various deposits of sediments, weather conditions and erosion. So to overcome this problem, several indices should analyze and compare them with other exist data such as remote sense, seismic data and field evidence.

In this research, three significant morphometric indices were analyzed: drainage basin asymmetry (Af), drainage basin shape (Bs) and mountain front sinuosity (Smf) in the Tehran city and adjacent mountains ranges. These indices were assigned in different tectonic classes based on the range of values of individual geomorphic indices are after that, they were summed and divided into an index of relative active tectonics (IRAT). For evaluation of Drainage Basin Asymmetry factor and Drainage Basin Shape Index, a digital elevation model (DEM) of the study area was produced. By using the Arc GIS software, Global Mapper and Google Earth data an Elevation and Drainage network maps was made. Different indices in the north and east part of Tehran city (13 sub-basins) were analyzed. In the west and South part of Tehran it could not be evaluate even on topographic map in scale of 1:25,000, because of flatness and low altitude of that area, therefore in present study north and east part of city were focused (Figure 2).

\subsubsection{Drainage Basin Asymmetry Factor (AF)}

The asymmetry factor (AF) is widely used to evaluate the existence of tectonic tilting at the scale of a drainage basin. AF is defined by,

$$
\mathrm{AF}=\mid(\text { Ar/At }) \times 100-50 \mid
$$

where "Ar" is the area in right side of the basin of the stream, "At" is the total area of the drainage basin and both were quantified in ArcGIS and Global Mapper. Change in inclination perpendicular to the stream direction and also the tectonic activity have direct effect on "AF". In active area, the steep side of mountainous is formed by displacement two sides of faults and this displacement leads 

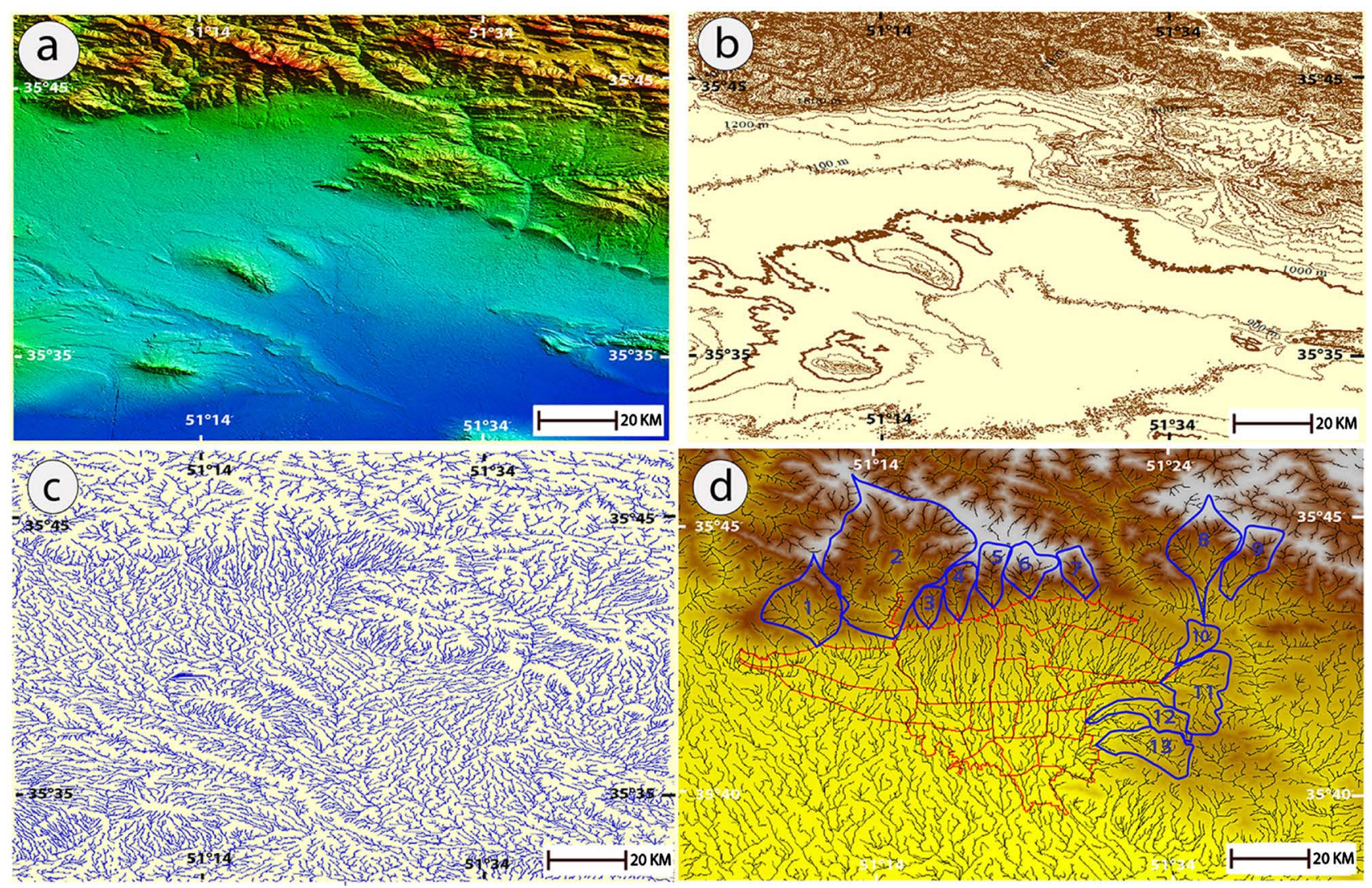

Figure 2. (a) DEM of studied area 1:30,000 m (Download from USGS site), (b) \& (c) Elevation and drainage basin maps of studied area (prepared from Mentioned DEM in Global Mapper software), (d) Location of 13 Drainage Basin map of study area (Red line point out Tehran regions).

the basin tilting and causes the river to migrate and Stray from the midline of basin. Furthermore, structural control of the orientation of bedding could has effect on development of basin asymmetry and tilting of bedding allows for preferred migration of the valley in the down side, producing an asymmetric valley [3]. "AF" bigger than 50 shoes tilting to left, equal with 50 shows symmetry and No tilting and smaller than 50 shows tilting to right. In asymmetry situation, it shows influence of lithologic control, differential erosion or active tectonics [11] [12] [18] [1] (Figure 3).

The "Ar", "At" and "AF" in 13 basin (Figure 2(d)) of the Tehran were calculated and the "AF" index map was made from the measured "AF" values for evaluation of tectonic activity. The "AF"-50 value is the amount of difference between the neutral value of 50 and the calculated "AF" value. For the purpose of evaluating the relative active tectonics, the absolute difference is what is important, and values of "AF"-50 range from 2 (sub-basin 4) to 16 (sub-basin 9). AF values were divided into three classes: class 1 ( $\mathrm{AF}>6$ ); class 2: $(3>\mathrm{AF}<6)$, and class $3(\mathrm{AF}<3)$ (Figure 3; Table 1 and Table 4). As it reports on the Table 1, sub-basin 1, 3, 8, 9, 12 and 13 are categorized in class 1 , sub-basin 2, 6, 10 and 11 in class 2 and sub-basin 4, 5 and 7 in class 3 (Table 1 and Table 4). 

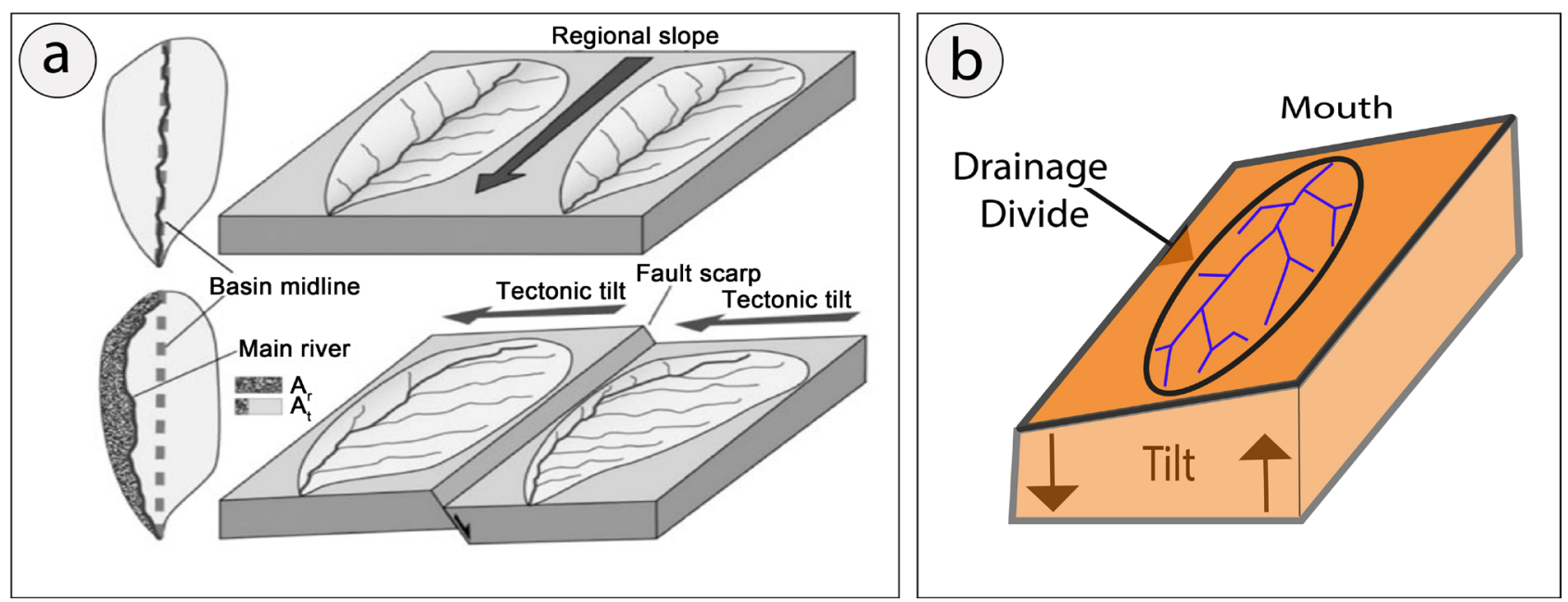

Figure 3. (a) Drainage response to uplift along a fault by migrating laterally in a down-tilt direction (retrieved from [18]); (b) Example of the calculation for drainage basin asymmetry (modified from [20]).

Table 1. The result of drainage basin asymmetry factor (Af) analyzing in the 13 regions of sub-basin in Tehran city.

\begin{tabular}{cccccc}
\hline Basin no. & Ar $\left(\mathrm{km}^{2}\right)$ & At $\left(\mathrm{km}^{2}\right)$ & $\mathrm{AF}$ & Lithology of the valley floor & Class \\
\hline 1 & 43 & 66 & 15 & Andesitic Lava, Pyroclastic and tuff & 1 \\
2 & 90 & 192 & 3.2 & Andesitic Lava, Pyroclastic and tuff & 2 \\
3 & 8 & 13 & 11 & Andesitic Lava, Pyroclastic and tuff & 1 \\
4 & 10 & 21 & 2 & Andesitic Lava, Pyroclastic and tuff & 3 \\
5 & 9.5 & 20.3 & 3 & Andesitic Lava, Pyroclastic and tuff & 3 \\
6 & 12 & 22 & 5 & Andesitic Lava, Pyroclastic and tuff & 2 \\
7 & 9 & 17 & 2.9 & Andesitic Lava, Pyroclastic and tuff & 3 \\
8 & 28.9 & 66 & 6.2 & Andesitic Lava, Pyroclastic and tuff & 1 \\
9 & 13 & 38 & 16 & Andesitic Lava, Pyroclastic and tuff & 1 \\
10 & 6.1 & 13.8 & 5.8 & Conglomerate and tuff & 2 \\
11 & 31 & 57 & 5 & Shale, Sandstone and Conglomerate & 2 \\
12 & 13 & 30 & 7 & Conglomerate, Limestone and Dolomite & 1 \\
13 & 18.9 & 43.1 & 6.1 & Conglomerate, Limestone and Dolomite & 1 \\
\hline
\end{tabular}

\subsubsection{Drainage Basin Shape Index (Bs)}

Rapidly uplifted mountain fronts generally produce elongated and steep basins [21]. In active tectonic areas, the shape of young drainage basins relatively are elongated in parallel to the topographic slope of a mountain. When tectonic activity reduces by continued topographic evolution, the elongated shapes are changed into circular basins [10]. The reason of this shape changing is because where the stream's energy has been directed to down cutting, the shape of drainage basin are narrower near the high elevation in mountain front; and in opposite, when the elevation decrease, the shape of drainage basin changes to circle. The horizontal projection of a basin may be described by the basin shape index 
or the elongation ratio, Bs [21] or elongation ratio is expressed as:

$$
\mathrm{Bs}=\mathrm{Bl} / \mathrm{Bw}
$$

where "Bl" is the basin's length, and "Bw" is the basin's width. High values of "Bs" show the elongated basins and generally associated with relatively higher tectonic activity. Low values of "Bs" show circular shaped of basin, and generally associated with low tectonic activity. Therefore, "Bs" is related to the rate of active tectonics. "Bs" was calculated by using the DEM and classified into three classes: class 3 (inactive (Bs $<3)$ ); class 2 (semi active $(3<\mathrm{Bs}<4)$ ) and class 1 (active $(4<\mathrm{Bs}))$ [10] \& [21]. Computations show that sub-basin 4 has the lowest Bs value (1.4) and sub-basin 12 has the highest (5.5) (Table 2 and Table 4). As it reports on the Table 2, sub-basin 8, 9, 12 and 13 are categorized in class 1, sub-basin 1 and 3 in class 2 and sub-basin 2, 4, 5, 6, 7, 10 and 11 in class 3 (Figure 4).

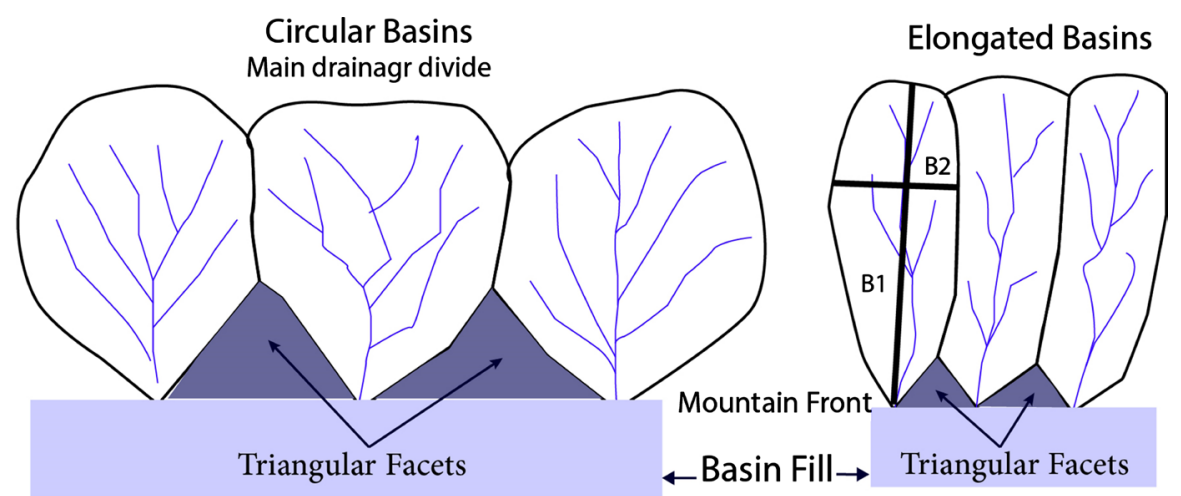

Figure 4. Relation between basin shape and morphology of the mountain front (retrieved from [19]).

Table 2. The result of drainage basin shape index (Bs) analyzing in the 13 sub-basin in Tehran city.

\begin{tabular}{cccccc}
\hline Basin no. & Bl $(\mathrm{km})$ & Bw $(\mathrm{km})$ & Bs & Lithology of the valley floor & Class \\
\hline 1 & 11.5 & 3.6 & 3.2 & Andesitic Lava, Pyroclastic and tuff & 2 \\
3 & 23.3 & 11.5 & 2.1 & Andesitic Lava, Pyroclastic and tuff & 3 \\
4 & 7 & 2.2 & 3.2 & Andesitic Lava, Pyroclastic and tuff & 2 \\
5 & 9.7 & 3.2 & 3 & Andesitic Lava, Pyroclastic and tuff & 3 \\
6 & 9.4 & 3.6 & 2.9 & Andesitic Lava, Pyroclastic and tuff & 3 \\
7 & 7.6 & 4.8 & 1.6 & Andesitic Lava, Pyroclastic and tuff & 3 \\
8 & 7.3 & 2.5 & 2.9 & Andesitic Lava, Pyroclastic and tuff & 3 \\
9 & 33.6 & 8.2 & 4.1 & Andesitic Lava, Pyroclastic and tuff & 1 \\
10 & 14.3 & 2.9 & 4.5 & Andesitic Lava, Pyroclastic and tuff & 1 \\
11 & 6.2 & 2.8 & 2.2 & Conglomerate and tuff & 3 \\
13 & 13.8 & 10 & 1.4 & Shale, Sandstone and Conglomerate & 3 \\
\hline 14 & 13.9 & 3.2 & 4.4 & Conglomerate, Limestone and Dolomite & 1 \\
\hline
\end{tabular}




\subsubsection{Mountain Front Sinuosity (Smf)}

The mountain fronts were evaluated by using "Smf" index [14] [19] and it signifies a good balance between active vertical tectonics and the processes of the stream erosion [10] [22]. In active mountain fronts, uplift caused erosional processes with high rate and as a result, yielding straight fronts with low values of "Smf". In the low active area, erosional processes generate sinuous and irregular fronts with high values of "Smf". Mountain front sinuosity index "Smf" ([9] is defined as:

$$
\mathrm{Smf}=\mathrm{Lmf} / \mathrm{Ls}
$$

where "Lmf" is the mountain front's length along the mountain piedmont junction(the topographic break in the slope), and "Ls" is the mountain front's length that is measured along a straight line [19]. Most active mountain fronts show "Smf" values ranging between 1.0 and 1.4 [22], whereas less active and inactive mountain fronts have "Smf" values shoe the ranging between $1.4-3.0$ and > 3.0, respectively [9] [10]. The values of "Smf" were calculated for the 11 area in mountain fronts using Lmf and Ls values measured from ASTER GDEM elevation model with a spatial resolution of $30 \mathrm{~m}$ and divided into three classes: class $1(1.1-1.4)$ ), class 2 (active $(1.4-3.0)$ ) and class 3 (inactive $(>3.0)$ ) as shown in Figure 5 and Table 3 and Table 4. Computations show that the Mountain front no.6, 10 and 11 has the lowest "Smf" value (1.4) and classified in the class 1 and Mountain front no. 2 has the highest (2.6) and Mountain front no. 1 till 5 and 7 till 9 with are classified in class 2 (Table 3 and Table 4). Base on Mountain Front Sinuosity analysis result, the East North and East South part of Tehran is active (Somewhat matching as the result of other geomorphology index).

\subsection{Relative Tectonic Activity}

Relative tectonic activity is regularly evaluated by at list two main morphometric indices,

Table 3. Mountain front sinuosity index of study area.

\begin{tabular}{ccccccc}
\hline $\begin{array}{c}\text { Mountain } \\
\text { front no }\end{array}$ & $\begin{array}{c}\text { Lmf } \\
(\mathrm{km})\end{array}$ & $\begin{array}{c}\text { Ls } \\
(\mathrm{km})\end{array}$ & Smf & Fault & Lithology of mountain front & Class \\
\hline 1 & 15.1 & 6 & 2.5 & NTF & Andesitic Lava, Pyroclastic and tuff & 2 \\
2 & 19.91 & 7.6 & 2.6 & NTF & Andesitic Lava, Pyroclastic and tuff & 2 \\
3 & 14.6 & 5.8 & 2.5 & NTF & Andesitic Lava, Pyroclastic and tuff & 2 \\
4 & 12 & 5.2 & 2.3 & NTF & Andesitic Lava, Pyroclastic and tuff & 2 \\
5 & 30.51 & 18.5 & 1.6 & NTF & Andesitic Lava, Pyroclastic and tuff & 2 \\
6 & 8.68 & 6.16 & 1.4 & NTF \& MF & Andesitic Lava, Pyroclastic and tuff & 1 \\
7 & 4.7 & 2.2 & 2.2 & Narmak & Conglomerate & 2 \\
8 & 11.6 & 5.7 & 2 & Kosar & Conglomerate & 2 \\
9 & 7.019 & 4.7 & 1.5 & Amin Abad & Dolomite and Limestone & 2 \\
11 & 8.56 & 6.16 & 1.4 & Parchin & Conglomerate, Limestone and Dolomite & 1 \\
\hline & 9.8 & 7.1 & 1.4 & Parchin & Conglomerate & 1 \\
\hline
\end{tabular}




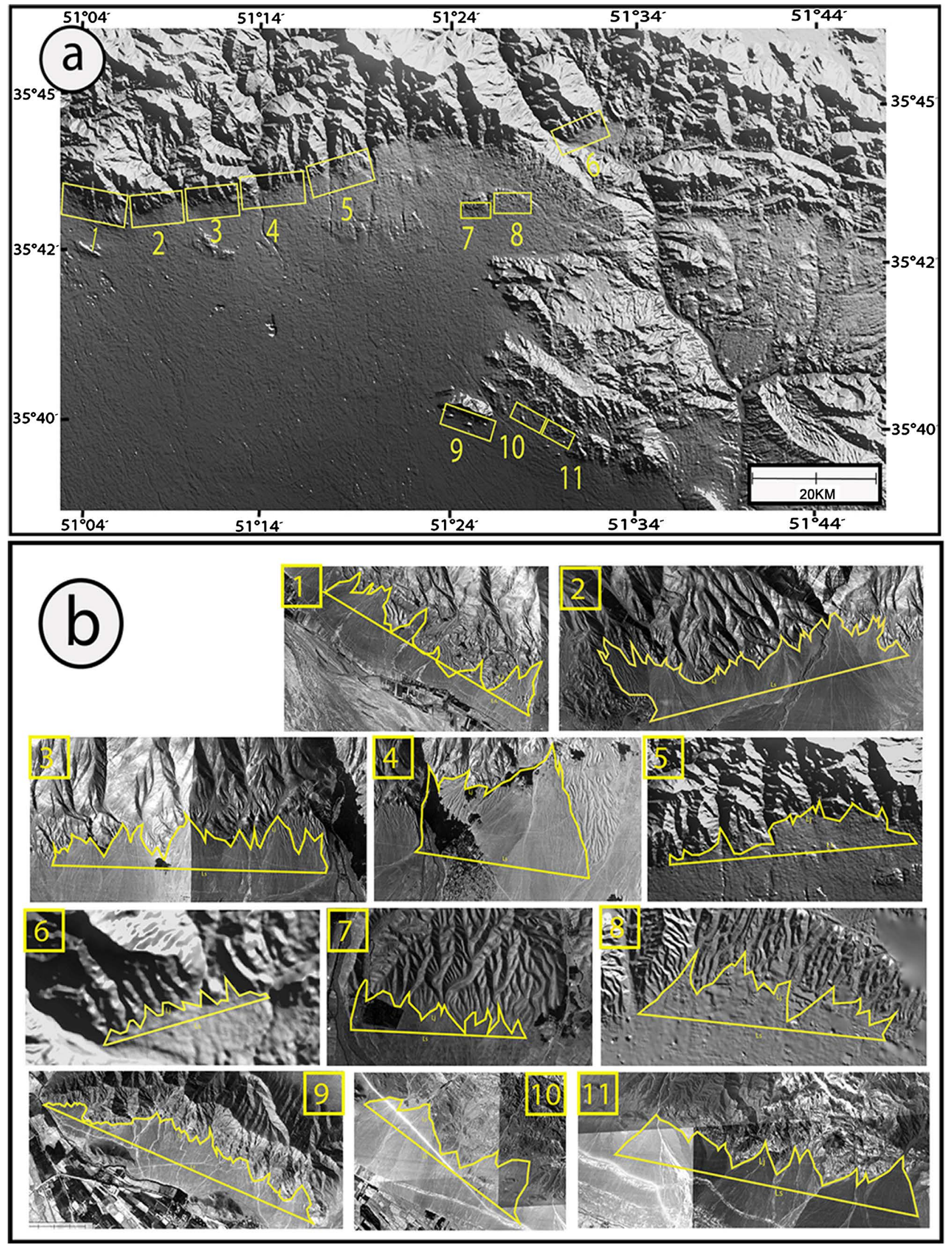

Figure 5. 11 area in mountain fronts of Central Alborz Mountain for calculating the "Smf" index on Aerial photo (1:55,000 scale). 
Table 4. Relative tectonic activity class base on Af, Bs and Smf index of study area.

\begin{tabular}{|c|c|c|c|c|c|c|c|c|c|c|c|c|}
\hline Area & Fault & Lithology of the valley floor & $\begin{array}{c}\text { Basin } \\
\text { no. }\end{array}$ & $\mid$ AF-50 $\mid$ & $\begin{array}{l}\text { Class } \\
(\mathrm{AF})\end{array}$ & Bs & $\begin{array}{l}\text { Class } \\
\text { (Bs) }\end{array}$ & $\begin{array}{c}\text { Mountain } \\
\text { front no. }\end{array}$ & Smf & $\begin{array}{l}\text { Class } \\
(\mathrm{Smf})\end{array}$ & $\begin{array}{c}\text { Average } \\
\text { Class }\end{array}$ & $\begin{array}{l}\text { Class } \\
\text { RTA }\end{array}$ \\
\hline West North & North Tehran & Andesitic Lava, Pyroclastic and tuff & 1 & 15 & 1 & 3.2 & 2 & 1 & 2.50 & 2 & 1.7 & 2 \\
\hline West North & North Tehran & Andesitic Lava, Pyroclastic and tuff & 2 & 3.2 & 2 & 2.1 & 3 & 2 & 2.61 & 2 & 2.3 & 3 \\
\hline West North & North Tehran & Andesitic Lava, Pyroclastic and tuff & 3 & 11 & 1 & 3.2 & 2 & 3 & 2.50 & 2 & 1.7 & 2 \\
\hline Middle North & North Tehran & Andesitic Lava, Pyroclastic and tuff & 4 & 2 & 3 & 3 & 3 & 4 & 2.32 & 2 & 2.7 & 3 \\
\hline Middle North & North Tehran & Andesitic Lava, Pyroclastic and tuff & 5 & 3 & 3 & 2.9 & 3 & 5 & 1.65 & 2 & 2.7 & 3 \\
\hline Middle North & North Tehran & Andesitic Lava, Pyroclastic and tuff & 6 & 5 & 2 & 1.6 & 3 & - & - & - & 2.5 & 3 \\
\hline Middle North & North Tehran & Andesitic Lava, Pyroclastic and tuff & 7 & 2 & 3 & 2.9 & 3 & - & - & - & 3 & 3 \\
\hline North East & NTF \& MF & Andesitic Lava, Pyroclastic and tuff & 8 & 6.2 & 1 & 4 & 1 & 6 & 1.4 & 1 & 1 & 1 \\
\hline North East & Mosha & Andesitic Lava, Pyroclastic and tuff & 9 & 16 & 1 & 4.5 & 1 & - & - & - & 1 & 1 \\
\hline East & Narmak & Mountain front no. & - & - & - & - & - & 7 & 2.18 & 2 & 2 & 2 \\
\hline East & Kosar & Mountain front no. & - & - & - & - & - & 8 & 2.05 & 2 & 2 & 2 \\
\hline East & Ghasre Firuze & Conglomerate and tuff & 10 & 5.8 & 2 & 2.2 & 3 & - & - & - & 2.5 & 3 \\
\hline East & Ghasre Firuze & Shale, Sandstone and Conglomerate & 11 & 5 & 2 & 1.4 & 3 & - & - & - & 2.5 & 3 \\
\hline South East & Amin Abad & Dolomite and Limestone & - & - & - & - & - & 9 & 1.48 & 2 & 2 & 2 \\
\hline South East & Parchin & Conglomerate, Limestone and Dolomite & 12 & 7 & 1 & 5.5 & 1 & 10 & 1.39 & 1 & 1 & 1 \\
\hline South East & Parchin & Conglomerate, Limestone and Dolomite & 13 & 6.1 & 1 & 4.4 & 1 & 11 & 1.38 & 1 & 1 & 1 \\
\hline
\end{tabular}

and investigations generally focus on a typical mountain front [10] [13]. As explained above, 3 asymmetry factor (AF), basin shape index (Bs) and mountain front sinuosity in areas affected by the active faults were analyzed. In order to differentiate values as the index related to rock resistance, different levels of average rock strength were defined (by using existing Lithology type map of study area). Classification of Frontal Mountain based on relative tectonic activities is a new relative method and the results obtained from these three indices were combined to yield an index of relative active tectonics (IRAT) using GIS. The average of the three measured geomorphic indices were used to evaluate the distribution of relative tectonic activity in the study area. Three classes were defined to define the degree of relative tectonic activity: class 1 , high $(1.0>$ IRAT $<1.5)$; class 2 , moderate $(1.5>$ IRAT $<2)$ and class 3 , low $(2>$ IRAT) (Table 4). Relative tectonic activity is the final goal in this process and the "Smf", "Bs", and "Af" indices are the main elements and basic layers in this assessment. Anyhow in this research in comparison of others, South East, North East and North West, of Tehran have the most level of relative tectonic activity and North middle of Tehran (Middle part of NTF) fault has the least level.

\subsection{Remote Sensing and Field Evidence of Neo-Tectonics}

Some types of observations can be searched in satellite imagery, area photo, dig- 
ital topography and field out crop investigation in order to assess the potential for activity of area. Late Quaternary activity can be determined from the lateral displacement of young landforms such as offsetting across the water ways, tilting of Quaternary layers, the existence of fault Scarp and several rivers terrace and alluvial fans. In steep terrains such as the Alborz foothills, erosion rates are very high and fluvial incision has produced a landscape whit variable degree of dissection. Straight mountain fronts with triangular facets along the active faults are widespread in south of central Alborz mountain. Their development appears to be controlled by active tectonics, and therefore they record information about the Quaternary landscape evolution and several stages of uplift. In Figure 6, and Figure 7 the offsetting of alluvial fan, displacement of layer, evidences of reverse faulting are clear on the area photo. All of this evidence confirm the tectonic activity of the study area.

Also in field investigation, several out crop in the SE, NW and NE of Tehran City were exposed that the trace of Faults caused running of Miocene rock over recent alluvial deposit. Two alluvial deposits samples that were taken from out crops of NTF in Vardij and Kan road (WN of Tehran city) by using C. 14 Dating method (Institute of Accelerator Analysis Ltd., Japan) obtained ages $~ 7$ till $8 \mathrm{ka}$, approved that The TNF in west north side was active in Holocene. Also in the other out crop in the SE of Tehran, the trace of Amin Abad fault caused running of Dolomitic Limestone with Tertiary age over Quaternary alluvium (Figure 8).

\subsection{Seismicity of the Region}

\subsubsection{Historical Earthquake}

Historical studies have shown that Shahr Rey, the former capital of Iran and

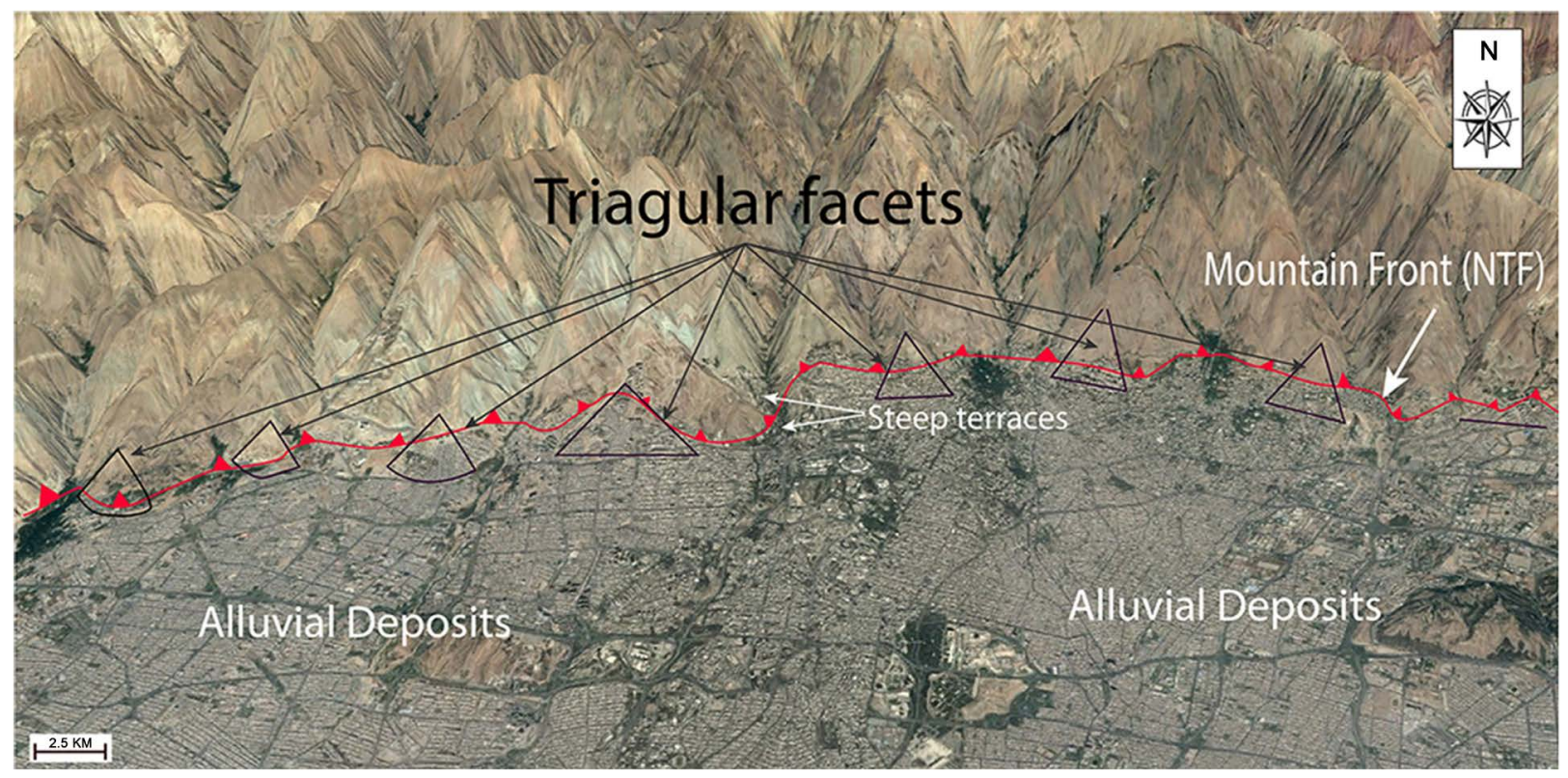

Figure 6. Google map view of north Tehran city (southern of the Alborz Mountains), with active mountain fronts, showing steep, with fault scarps, triangular facets, alluvial deposits and terraces due to high incision. North Tehran Fault (NTF) was marked by red line. 


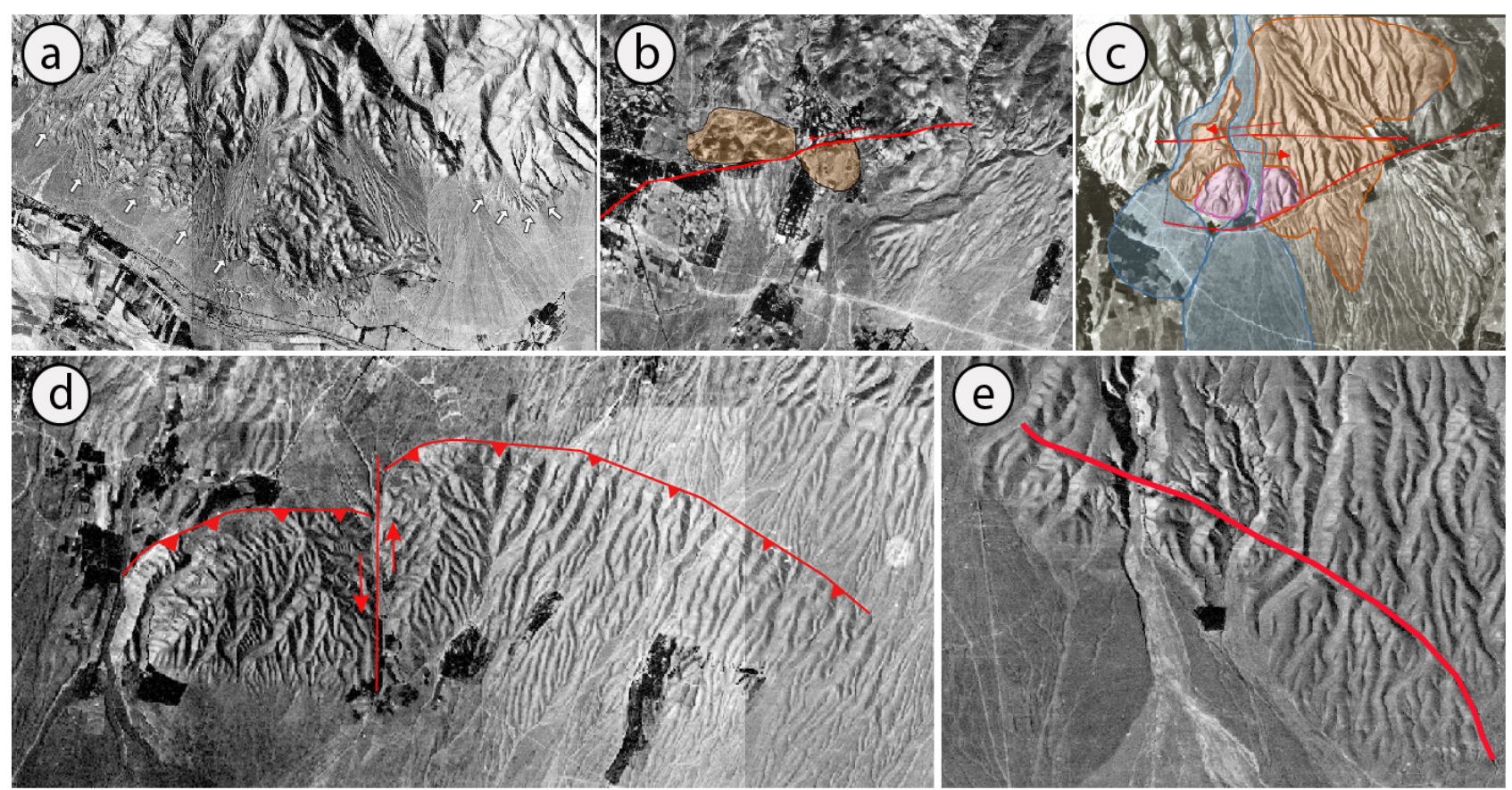

Figure 7. Aerial photo (1:55,000 scale), (a) evidences of reverse faulting on EW-SE Direction of NTF in West north Tehran (White arrows point out NTF fault scarp affecting alluvial fans), (b) and (c) offsetting of the alluvial fan ("C" Formation (late Pleistocene age)) with left lateral strike-slip, Niavaran Fault. (d) N_S Lavizan strike-slip fault with sinistral mechanism, (e) tilting of water way on the Baghe-Feiz anticline.
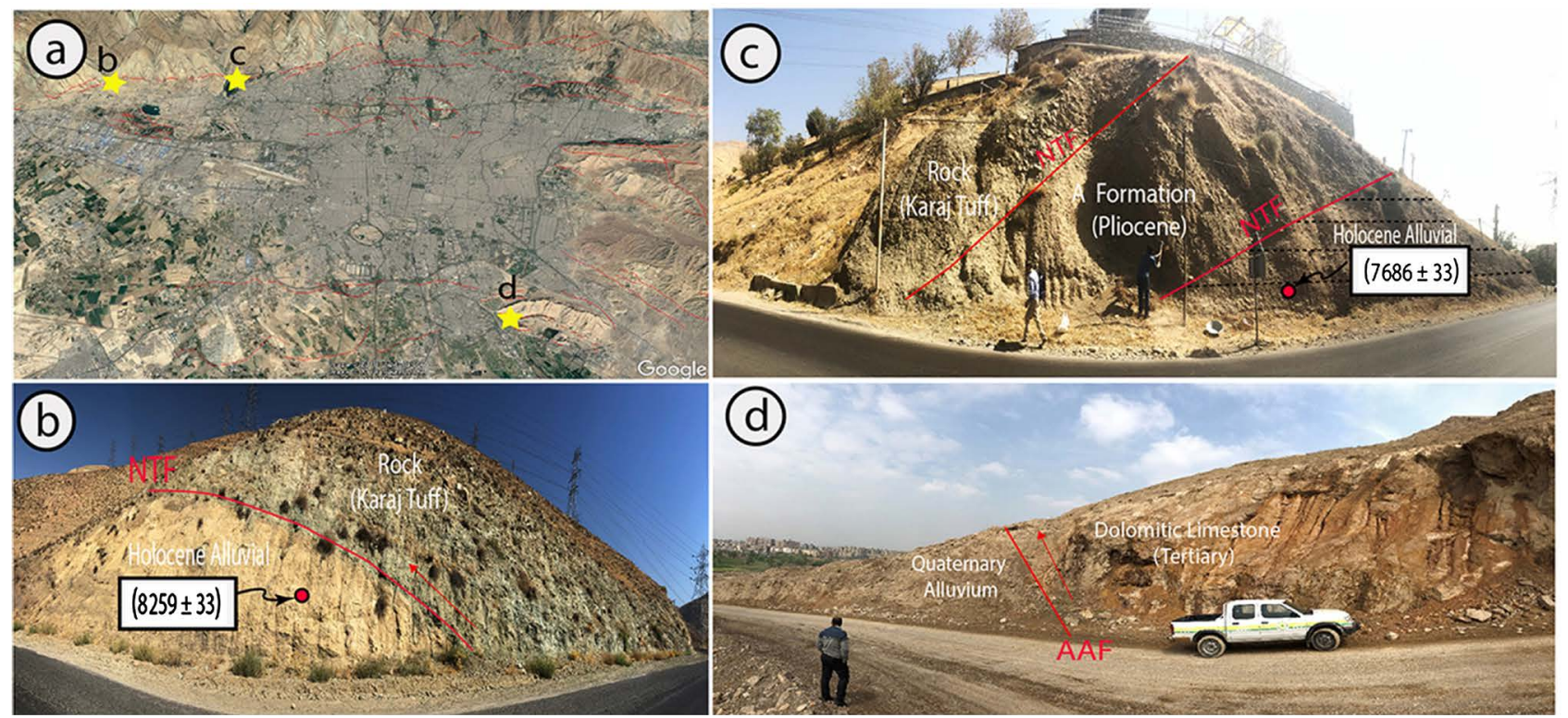

Figure 8. Trace of fault caused running of rock over the recent alluvial deposits on active fault zone of SE, (a) the location of fault trace are clear on the Google Earth view; (b) Trace of NTF in the Vardij road caused running of Karaj Formation rock over the Holocene Alluvial Deposit with age of $8.259 \pm 33$; (c) Trace of NTF in the Kan road caused running of Karaj Formation rock over the Holocene Alluvial Deposit with age of $7.686 \pm 33$ and (d) trace of Amin Abad Fault (AAF) in the SE of Tehran.

to-day a southern suburb of Tehran, has been devastated by earthquakes a number of times in the past but unfortunately none of the descriptions by which these events are known are sufficiently detailed to allow an accurate assessment 
of destruction and ground deformation (e.g. [5] [23]-[28]). On the basis of these historical studies, it would appear that the Tehran region has not experienced any major destructive earthquakes at least since the beginning of the 19th century. Among historical earthquakes, the events of 855 - $856 \mathrm{AD}(\mathrm{M} \sim 7.1)$ and $1177 \mathrm{AD}(\mathrm{M} \sim 7.2)$ could be associated with the Kahrizak, North Rey and South Rey thrust faults(three E-W trending fault located in the southern Tehran plain) [26]. The $1384 \mathrm{AD}$ destructive Rey region earthquake, has also been located on Pishva Fault [29]. Where paleoseismological evidence of the last event (in 1830 AD: M 7.1) found along Mosha-North Tehran Fault system within north of the region [30] (Figure 9).

\subsubsection{Instrumental Earthquake}

Micro-earthquake studies are an important part of seismological researches in active area. Results from such studies are usually integrated with other information and theoretical investigations in order to understand Seismo-genesis and activity of area. Micro-earthquakes have long been studied in Tehran zone [31]. In this study, the micro-earthquakes around Tehran (the permanent local seismological network of the IRSC, "Iranian Seismological Center") were downloaded. They are included all latest earthquakes with magnitudes bigger than 2.5, detected in Tehran from 2006 to 2017 [32]. Based on this recent data, three important earthquakes occurred two of them in the south of Tehran (17 October 2009, Mw $=4.0$, and 20 February 2011, Mw $=4.1$ ) near the Eyvanekey Fault and the recent on in the North West (20 December 2017, Mw 5.2), intersection between Eshtehard and North Tehran Faults. This might be taken as a warning of activity in this area. The distribution of those micro-earthquakes, was plotted in Figure 9. The combined historical records for earthquakes and instrumental seismicity of the region recorded recently shows that the SE, NE and NW of Tehran is more active respectively. North Middle of the Tehran, in particular do not seem to be as seismically active as the NW, NE and SE of Tehran.
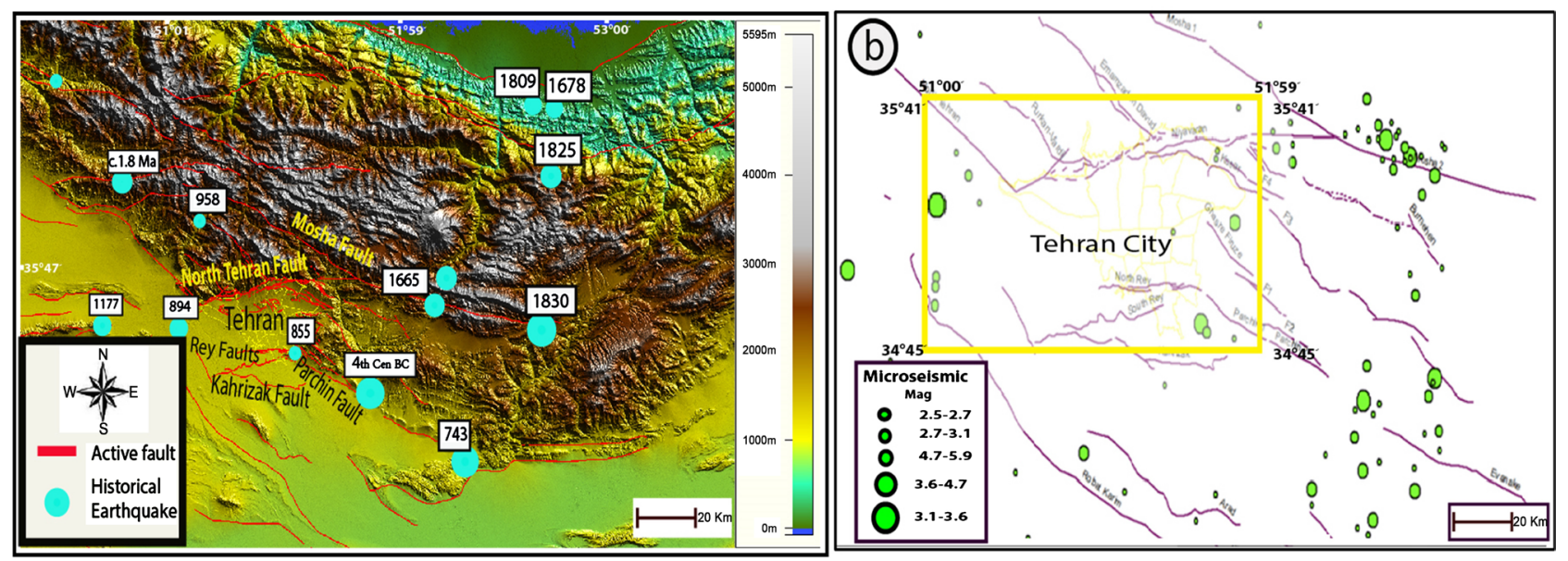

Figure 9. (a) Historical seismicity of north-central Iran (modified of [24] [26] and [30]); (b) Epicenter of instrumental earthquakes of the Tehran, records during past 11 years (the epicenters of these earthquakes have been taken from geophysics institute site of Tehran university from 2006 till 2017 and have been analyzed in ARC GIS software in scale 1:250,000). 


\section{Discussion}

The geomorphic indices are known as one of powerful tools for evaluating the influence of active tectonics. In the mountains where tectonic activities are high, like gathering locations of active folds and faults, the effect of their activity, clearly is shown by geomorphic indices.

In the area, by using GIS and remote sensing data (DEM and imagery), these indices can be used as a reconnaissance tool to notice the geomorphic anomalies that are related to tectonic activity. Where relatively little work on active tectonics based on absolute dating is available, (e.g. when there as limitation in field investigation such as Military Areas (some part of eat Tehran) or high mountain range to climb (some part of north Tehran)), this method becomes extremely valuable. In this research, three significant morphometric indices were analyzed: drainage basin asymmetry (Af), drainage basin shape (Bs) and mountain front sinuosity (Smf). These indices were assigned in different tectonic classes based upon the range of values of individual geomorphic indices. These classes are then summed and averaged and arbitrarily divided into an index of relative active tectonics (IRAT) over the entire study area. For evaluation of Drainage Basin Asymmetry factor and Drainage Basin Shape Index, A Drainage network map was produced by using of digital elevation model (DEM) and different indices were analyzed in 13 sub-basins. The Drainage Basin Asymmetry factor (AF) were changed from 2 (sub-basin 4) to 16 (sub-basin 9) and them were divided into three classes: Sub-basin 1, 3, 8, 9, 12 and 13 are categorized in class 1, sub-basin 2, 6, 10 and 11 in class 2 and sub-basin 4, 5 and 7 in class 3 (Figure 3). The Drainage Basin Shape Index (Bs) were changed from 1.4 (sub-basin 4) till 5.5 (sub-basin 12) and them were divided in three class: sub-basin 8, 9, 12 and 13 are categorized in class 1, sub-basin 1 and 3 in class 2 and sub-basin 2, 4, 5, 6, 7, 10 and 11 in class 3 (Figure 4). For Mountain Front Sinuosity (Smf) 11 area were selected (Figure 5). This factor were changed from 1.4 (Mountain front no.6, 10 and 11) till 2.6 (Mountain front no 2) and them were divided in 2 class: Mountain front no. 6, 10 and 12 categorized in class 12 and Mountain front no. 1 till 5 and 7 till 9 are classified in class 2 (Table 3 and Table 4).

Finally the average of the three measured geomorphic indices were used to evaluate the distribution of relative tectonic activity in the study area (Table 4). Three classes were defined to define the degree of relative tectonic activity: class 1 , high $(1.0>$ IRAT $<1.5)$; class 2 , moderate $(1.5>$ IRAT $<2)$ and class 3 , low (2 > IRAT) (Table 4).

It is necessary to express that, due to the impact of various factors such as various deposits of sediments, weather conditions and erosion,. some error would be inevitable in this method results, So to overcome to this problem, field investigation was carried out and remote sensing study have been done base on satellite image, aria photos and Google Earth view. As it is clear in the figure6, In the Google map view of north Tehran city (southern of the Alborz Mountains), evidence of the activity of mountain fronts, are clear such as: fault scarps, trian- 
gular facets, alluvial deposits and terraces due to high incision and offsetting of alluvial fan. In Figure 7, in the aerial photo, the evidences of tectonic activity of Faults can were observe clearly such as reverse faulting trace of EW-SE Direction of NTF in West north Tehran on the alluvial fans (Figure 7(a)), offsetting of the alluvial fan ("C" Formation (Quaternary)) with left lateral strike-slip Niavaran Fault (Figure 7(b) \& Figure 7(c)), N-S-oriented strike slipe fault with sinistral mechanism that located on "A" and "B" Formation (late Pliocene) (Figure $7(\mathrm{~d})$ ) and tilting of water way on the Baghe-Feiz anticline (Figure $7(\mathrm{e})$ ). Also in field investigation, the trace of NTF was detected in some out crop with $\sim 7$ till 8 ka. age in the NW of Tehran City (Figure 8(b) and Figure 8(c)) and the trace of Amin Abad Fault that caused running of Dolomitic Limestone over Quaternary deposits in Amin Abad Mountain (SE of Tehran City).Finally the obtained results were compared with exist historical earthquake and micro-seismic records during past 11 years (2006 till 2017). This comparing shows that the many historical earthquakes and micro-earthquakes occurred in the study region happened in SE, NE and NW of Tehran, consistent with our results. Also field evidence and remote sense make it clear that the faults effects on the terrace risers and alluvial fans in the late Quaternary and Holocene, indicating the current activity of these faults in the high rate of Relative tectonic activity (RTA) area that were obtain from Geomorphic Indices.

\section{Conclusions}

- For evaluation tectonic activity of metropolis Tehran City (Iran), three geomorphic indices (basin asymmetry factor (AF), basin shape index (Bs) and mountain front sinuosity $(\mathrm{Smf})$ ) were evaluated and the obtained average results of relative tectonic activity show three classes: class 1 , high $(1.0>$ IRAT < 1.5); class 2, moderate $(1.5>$ IRAT $<2)$ and class 3 , low $(2>$ IRAT $)$ in the study area.

- In the North and East of Tehran City, the remote sense and out crops investigation, confirm late Quaternary activity by mentioned to lateral displacement of young landforms and running of Miocene and Tertiary rock over recent alluvial deposit; also combined historical earthquakes and instrumental seismicity of the region, shows most activities are focused in the WN, EN and ES of Tehran.

- The remote sense, field investigation, historical earthquakes and instrumental seismicity results match well with the geomorphic indices and IRAT results. The result confirm that the ES of Tehran (Pishva Fault), EN (Connect area) between North Tehran Fault (NTF) and Mosha Fault and WN of Tehran (west of NTF), have the most level of relative tectonic activity (RTA) respectively.

\section{Highlights}

- Topographic divides and geomorphology features study of Tehran City con- 
firm that this area that is located on the pediment zone of Alborz Mountain, tectonically is active.

- In the North and East on Tehran city, the late Quaternary-Holocene sedimentary layer was effected by active faults of area.

- Combining of the geomorphic indices with other Geology and seismicity date confirm that the ES of Tehran (Pishva Fault), EN (Connect area) between North Tehran Fault (NTF) and Mosha Fault and WN of Tehran (west of NTF), have the most level of relative tectonic activity (RTA) respectively.

\section{Acknowledgements}

At first we should Thanks Dr Sadeghi. A. Head of Tehran Disaster Mitigation and Management Organization (TDMMO) and Mrs Saleh. F. Mitigation and risk reduction deputy of TDMMO due to their constant support of our field work. In addition we are grateful to Profs. Zare. M, because of their recommendations in the early stages of this study. We are also grateful to N. Akiyama for arranging the field works. This work was partially supported by a Science Project grant from the Ministry of Education, Culture, Sports, Science and Technology of Japan.

\section{Conflicts of Interest}

The authors declare no conflicts of interest regarding the publication of this paper.

\section{References}

[1] Andermann, C. and Gloaguen, R. (2009) Estimation of Erosion in Tectonically Active Orogenies. Example from the Bhotekoshi Catchment, Himalaya (Nepal). International Journal of Remote Sensing, 30, 3075-3096. https://doi.org/10.1080/01431160802558733

[2] Perez-Pena, J.V. (2009) Spatial Analysis of Stream Power Using GIS: SLk Anomaly Maps. Earth Surface Processes and Landforms, 34, 16-25. https://doi.org/10.1002/esp.1684

[3] Cox, R.T. (1994) Analysis of Drainage-Basin Symmetry as a Rapid Technique to Identify Areas of Possible Quaternary Tilt-Block Tectonics: An Example from the Mississippi Embayment. Geological Society of America Bulletin, 106, 571-581. https://doi.org/10.1130/0016-7606(1994)106<0571:AODBSA>2.3.CO;2

[4] Addasi, M.R. and Farbod, Y. (2009) Faulting and Folding in Quaternary Deposits of Tehran, Piedmont (Iran). Journal of Asian Earth Sciences, 34, 522-531. https://doi.org/10.1016/j.jseaes.2008.08.001

[5] Tchalenko. J.S., et al. (1974) Tectonic Framework of Tehran Region. Geological survey of Iran Report, 29, 7-46.

[6] Stocklin, J. (1968) Structural History and Tectonic of Iran: A Review. American Association of Petroleum Geologists Bulletin, USA, 52, 1229-1258.

[7] Nilforoushan, F., et al. (2003) GPS Network Monitors the Arabia-Eurasia Collision Deformation in Iran. Journal of Geodesy, 77, 411-422.

https://doi.org/10.1007/s00190-003-0326-5 
[8] Vernant, P., et al. (2004) Deciphering Oblique Shortening of Central Alborz in Iran Using Geodetic Data. Earth and Planetary Science Letters, 223, 177-185. https://doi.org/10.1016/j.epsl.2004.04.017

[9] Bull, W.B. (2007) Tectonic Geomorphology of Mountains. Blackwell Publishing Ltd., 316 p.

[10] Bull, W.B. and Mc Fadden, L.D. (1977) Tectonic Geomorphology North and South of the Garlock Fault, California: In: Doehring, D.O., Ed., Geomorphology in Arid Regions Proceedings of the Eighth Annual Geomorphology Symposium, State University of New York, Binghamton, 115-138.

[11] Keller, E.A. and Pinter, N. (1995) Active Tectonics Earthquake, Uplift and Landscape. Prentice Hall Publisher, New Jersey.

[12] Keller, E.A. and Pinter, N. (1996) Active Tectonic. Prentice Hill, Upper Saddle River, NJ, 338.

[13] Rockwell, T., et al. (1985) Tectonic Geomorphology of Alluvial Fans and Mountain Fronts near Ventura, California, In: Morisawa, M., Ed., Tectonic Geomorphology, Proceedings of the 15th Annual Geomorphology Symposium, Allen and Unwin Publishers, Boston, MA, 183-207.

[14] Silva, P.G., et al. (2003) Fault Generated Mountain Fronts in Southeast Spain: Geomorphologic Assessment of Tectonic and Earthquake Activity. Gemorphology, 250, 203-226. https://doi.org/10.1016/S0169-555X(02)00215-5

[15] El Hamdouni, R., et al. (2008) Assessment of Relative Active Tectonics, Southwest Border of Sierra Nevada (Southern Spain). Geomorphology, No. 969, 150-173. https://doi.org/10.1016/j.geomorph.2007.08.004

[16] Mahmood, S.A. and Gloaguen, R. (2012) Appraisal of Active Tectonics in Hindu Kush: Insights from DEM Derived Geomorphic Indices and Drainage Analysis. Geoscience Frintiers Journal, 3, 407-428.

[17] Bagha, N., et al. (2014) Evaluation of Relative Tectonic Activity in the Tehran Basin Central Alborz, Northern Iran. Geomorphology, 213, 66-87. https://doi.org/10.1016/j.geomorph.2013.12.041

[18] Hamdouni, R.E., et al. (2008) Assessment of Relative Active Tectonics, Southwest Border of the Sierra Nevada (Southern Spain). Geomorphology, 96, 150-173.

[19] Keller, E.A. and Pinter, N. (2002) Active Tectonics Earthquake, Uplift and Landscape. Prentice Hall Publisher, Upper Saddle River, 362.

[20] Molin, P., et al. (2004) Geomorphic Expression of Active Tectonics in a Rapidly-Deforming Forearc, Sila Massif, Calabria, Southern Italy. American Journal of Science, 304, 559-589. https://doi.org/10.2475/ajs.304.7.559

[21] Ramirez-Herrera, M.T. (1998) Geomorphic Assessment of Active Tectonics in the Acambay Graben, Mexican Volcanic Belt. Earth Surface Processes and Landforms, 23, 317e332.

[22] Keller, E.A. (1986) Investigation of Active Tectonics: Use of Surficial Earth Processes. In: Wallace, R.E., Ed., Active Tectonics, Studies in Geophysics, National Academy Press, Washington DC, 136-147.

[23] Ambraseys, N.N. (1974) Historical Seismicity of North-Central Iran. In: Materials for the Study of Seismotectonics of Iran, North Central Iran, Geol. Surv. Iran, Rep. 29, 47-95.

[24] Amberaseyas, N.N. and Melville, C.P. (1982) A History of Persian Earthquakes. Cambridge University Press, London, 219.

[25] Berberian, M. (1981) Active Faulting and Tectonics of Iran. Department of Earth 
Sciences, Bullard Laboratories, University of Cambridge, Cambridge. https://doi.org/10.1029/GD003p0033

[26] Berberian, M., et al. (1985) Recent Tectonics, Seismotectonics, and Earthquake-Fault Hazard Study in the Greater Tehran Region (Contribution to the Seismotectonics of Iran, Part V). Geological Survey of Iran No. 56, 316.

[27] Berberian, M. and Yeats, R.S. (1999) Patterns of Historical Earthquake Rupture in the Iranian Plateau. Bulletin of the Seismological Society of America, 89, 120-139.

[28] Jackson, J., et al. (2002) Active Tectonics of the South Caspian Basin. Geophysical Journal International, 148, 214-245.

[29] Nazari, H., et al. (2009) Morphological and Palaeoseismological Analysis along the Taleghan Fault (Central Alborz, Iran). Geophysical Journal International, 178, 1028-1104. https://doi.org/10.1111/j.1365-246X.2009.04173.x

[30] Solaymani, A., et al. (2011) The Zandjan Fault System: Morphological and Tectonic Evidences of a New Active Fault Network in the NW of Iran. Tectonophysics, 506, 73-85.

[31] Mohajer-Ashjai, A. and Nowroozi, E.A. (1981) Seismicity and Active Tectonic Trends in Tehran Area. Iranian Petroleum Institute Bulletin, 77, 1-14.

[32] http://irsc.ut.ac.ir 